\title{
Perception, Preference, and Participation: Community Social Inclusion and Involvement as Decision Making Process in Architourism
}

\author{
Novi Sunu Sri Giriwati* \\ Department of Architecture, Faculty of Engineering, Universitas Brawijaya, Malang, Indonesia \\ *Corresponding author. Email: novie_gieriwati@yahoo.com
}

\begin{abstract}
Architecture and tourism are inseparable things. In tourism development, planning and design also carried out and generate some architectural design. The architectural product involved a user, who will respond in a certain way towards the architectural object and built environment in general. People design the environment, and the built environment modifies our deportment. It is important taking into consideration the perception, preference, and participation in the design process as the design is a decision making process. Perception is indeed a complex process involves integrating information through our senses, processing it, which implies analyzing the received information and comparing it against several gathered knowledge based on people's characteristics, experience, and psychology, which can affect the preference and participation. This paper addressed the importance and mechanism of community perception, preference, and participation in the tourism and architecture design process. Two case studies are analyzed using a qualitative approach. Through this research, it is indicated that the good perception and preference could generate participation. The participatory design could be a good method for the decision-making process in architourism. Keywords: Perception, preference, participation, decision making, architecture
\end{abstract}

\section{INTRODUCTION}

Taking the term of archi-tourism from Ockman's symposium on architecture and tourism (architourism), architecture definitely is a destination for tourism. There is a relationship between tourism and built space [1]. In this research, the term architourism refer to architecture and tourism development. Architecture has been recognized for its supporting role in enhancing the physical assets of tourist destinations. It plays a leading role in drawing tourists to come to one destination.

Architectural design has a contribution to tourism concerning planning and policy. It has an important value for tourism [2]. Architecture decisions can significantly affect architects and other roles [3]. The term of design could be explained as a process and product of thinking. While planning is making an arrangement. Design is an activity to generate and beautify the environment. Along with the critical remark, previous researcher was instrumental in questioning many of the postulates and being a great aid in the argument against considering architectural design as a problem-solving mentality [4].

The architecture product involved a user. The user is people who will react in a particular way towards the architectural object, built space, and the environment in general. People generate the environment through the designing process, and the built environment modifies our deportment [5]. Cuthbert, in 2006 posits that an aesthetically pleasing experience provides pleasurable sensory experiences, a pleasing perceptual structure, and pleasurable symbolic associations. This definition provides a useful guide as to the different levels of aesthetic perception that are necessary to judge a scene or setting. Aesthetic experience can be conceived in three levels: sensory perception, cognition, and meaning [6].

Perception is admittedly a very compound process that involves the assembly of information through our senses, processing it, which insinuates analyzing the received information and comparing it against previously gathered knowledge, based on past experiences, and formulating particular responses [4]. Unlike perception, preference refers to the relative attractiveness of an object, while choice refers to actual behavior. Preference is an expression of attractiveness, may guide choice, but the evaluation involved in preference may take place whether or not a choice has to be made. On the Theory of Planned Behavior it is refer to behavior model based on attitude and social norms [7]. Preference can drag people to make decisions, influenced by goals, cognitive constraints, and experience [8]. So, preference could be defined as what people choose or like. In terms of architecture, a decision can significantly affect architects and other roles [3], as well as in architourism.

The term participation means involvement in the development [9]. Participation refers to the balance between people's inclusion in the implicit and explicit decision-making processes within these fields, and their exclusion through the delegation of power [10]. Some previous studies have looked at the connection between 
perceptions, preferences, and participation both in architecture [5], [14], [32] and tourism [17], [27]. However, still not much research looks at the connectedness of the three in architourism. Based on this background, this paper addressed the importance of community perception, preference, and participation in the tourism and architecture design process. It is crucial to understand the functioning mechanism of the perceptual process, which will be analyzed in the first part of the paper.

The case studies in rural and urban are analyzed to help propose the participatory model. The first case study is Therapeutic Kampung ( $R W 3$ Sukun) in Malang city. It is an urban-educational settlement and tourist destination. In 2017, it has participated in the Malang design festival, a thematic kampung design competition held by Malang city government. In final result, this object failed become the top 10 winners and did not get financial support for infrastructure development. The competition did not dampen the community enthusiasm and participatory to develop settlement quality. Therapeutic Kampung ( $R W 3$ Sukun) received awards as bio-composter kampung, green kampung, and many others.

Universitas Brawijaya (UB) through Department of Architecture held development support activities in kampung terapi as part of institutional ceremony last year. UB has facilitated the community to provide children's playing facilities in a children-friendly alley. The architecture students help design children's play facilities and local community worked on the construction site.

The second case study is the Sumberwangi hamlet in the UB forest that is located on the slopes of Mount Arjuno. Since being given the Ministry of Environment's authority, UB manages this forest into an educational forest. One strategy is to develop Sumberwangi settlements into tourist accommodation facilities. The teaching staff, together with UB's forest manager and students, conducted a participatory tourism accommodation design.

\section{THEORETICAL FRAMEWORK}

Kampung can be defined as spontaneous informal settlements [11]. In Indonesia, informal urban settlements refer to kampung. In the Indonesian language (Bahasa), kampung means urban village, and it refer to an administrative unit [12], [13]. Kampung defined as an informal urban settlement for low-income people.

Defining perception is becoming increasingly difficult, precisely because it is the object of interdisciplinary and transdisciplinary studies. It tends to be broader or more restrictive, depending on the field of studies. Growing attention has been paid to the effect of the physical environment on human psychology and behavior in diverse academic fields, such as architecture, environmental psychology, and social. In the science of experimental psychology, perception can typify how stimuli act upon receptors, while in social psychologists, it signifies the ability to identify objects within the social environment, also includes the image which the individual forms upon various events, people, objects linked to previous experiences. The field of geography defines perception in a much broader sense, including the whole range of percepts, memories, attitudes, preferences, thus comprising the entire information we pose related to an environment, in fact, aspects that can be gathered under the term of environmental cognition [4].

The environment has a system of interacting with its inhabitants, called an encoding-decoding system, through which the meaning is embedded into the environment. Then, it is read by its users who thus know how to act or respond in that specific situation. Therefore, the physical form of the environment is very intimately linked to the culture (or subculture or even micro-culture) [5], or the physical environment is believed to be one of the most influential factors affecting a customer's psychological state and behaviors [33]. Space ought to speak the same language as the one who uses it, and it should be our duty to understand and learn that language. The clearer the messages, the cues transmitted, the more probable it is that the space we designed is going to be used within normal parameters [5].

James J. Gibson, a Psychological scientist in an ecological approach to visual perception, posits that people experience the surroundings directly and not through mediating stages of abstract processing by the brain [14]. Every person has different reactions, perceptions, and preferences to environmental stimuli resulting from complexity, partiality, and past experiences [32] related to emotional states than cognitive perception [33]. Human beings generally favor pleasant environments (whether arousing or unrousing) over unpleasant environments. One benefit of arousing and pleasant environments is the mental stimulation they provide. It turns out to be an important architectural and psychological consideration [32] [33]. Humans are the information processors, that prefer environments that provide an ample amounts of information to process [32].

Preference refers to the relative attractiveness of an object, while choice refers to actual behavior. Preference, as an expression of attractiveness, may guide choice, but the evaluation involved in preference may take place whether or not a choice has to be made. The Theory of Planned Behavior is a general theory to model behavior based on attitude, social norms [7]. Payne, introduced the multiple decision strategies in the construction of preferences. Framing effects, stimulus contexts, environments, and response modes might seem innocuous, but they can profoundly shape decisions. Preferences can reverse depending on each of these factors. These effects have important implications for policymaking, market decisions, and pollsters: 1). framing effect; 2). Stimulus contexts and environments; 3). Response mode effects [15]. The influence of psychological aspect is important for discovering a wider variety of ways to change to behavior and develop a mechanistic theory of how to make a decision [16]. Certain tourism scholars have adopted the framework of Arnstein's ladder of citizen participation (ALCP) to understand the expected and actual participation of the local community when involved in the 
decision-making process of tourism development [17], [18].

Some previous studies have looked at the interaction between preferences and people's characteristics, such as personality, attitudes, cognitive styles, learning orientations, and strategies [19], [20]. It highlighted the effect of personality on performance and subject choice. The personality can affect the preference [21], [22]. Furthermore, these studies from various researchers suggest that preferences are related to self-concept [23]. Many researchers used the concept of participation in their studies and found the importance of cooperating among community, professionals, and the administration to exchange information about user's demand and what can be done with available resources. An approved study by the user is that they are not a beneficiary from what is decided by the designer but they can make the decisions for themselves better than what professionals do. Therefore, the designer have to make other choices to meet the different needs. User dissatisfaction with one architectural object will support preferences and community participation [24].

Participation has its roots in the Latin words "pars" and "capere" which means "part" and "to take." The meanings of the word in English dictionaries often include the following; partaking in something, association with others in a relationship, social interaction in a group, and taking part with others in an activity [10]. Fredrik [11] defined participation as a general concept covering different forms of decision making by several parties involved. It can be active or passive, depending on the level of residents' involvement. Other study addressed users's participation as taking part with others, mainly the designers, to get proper quality of architecture object [24]. While in Japan, the term of community development or community participation is refer to Machizukuri. It defined as "community development", "neighborhood building", or "town making". It is a description of an extraordinarily wide variety of activities, from economic development initiatives to traditional top-down city planning or urban renewal projects and voluntary social welfare projects [34]. While Indonesia have the term "Gotong royong" which can refer to community participation.

Sanoff, the first researcher in participatory design, suggested a broader vision about community participation, which included involving users in social development such as a design decision, making the process, improve plans and promote a sense of community. There is no best solution to a design problem as each design problem has several solutions. Users' participation in the design usually has a scientific or significant background and needed as they can identify the problem better. It gives guides and controls the user's needs and designers to solve these problems [24]. Community participation is an approach to social development that required the creation of opportunities for all people to be politically involved and share in the development process [3].

There are several participation typology suggested by researchers. The participation typology as derived from Arnstein's (1969) is presented in Figure 1 [18], [9].

$\left.\begin{array}{cc}\hline 8 & \text { Citizen Control } \\ \hline 7 & \text { Delegated power }\end{array}\right]$ Degrees of citizen power

Figure 1 Arnstein's ladder of participation

According to Pretty's typology of participation, the participatory level is classified as 1). Manipulative participation: Pretending, with nominated representatives having no legitimacy or power; 2). Passive Participation: Unilateral announcements without listening to people's responses; 3). Participation by consultation: External agents define problems and information gathering processes, and so control analysis; 4). Participation for material incentives: People participate by contributing resources (labor) in return for material incentives; 5). Functional Participation: External agencies encourage participation to meet predetermined objectives; 6). Interactive Participation: People participate (as a right) in joint analysis, development of action plans, and formation or strengthening of local institutions; 7). Self-mobilization: People take initiatives independently of external institutions to change systems [18].

\begin{tabular}{cc} 
Pretty's Participation typology \\
\hline 7 & Self-mobilization \\
\hline 6 & Interactive Participation \\
\hline 5 & Functional Participation \\
\hline 4 & $\begin{array}{c}\text { Participation for Material } \\
\text { incentives }\end{array}$ \\
\hline 3 & $\begin{array}{c}\text { Participation by } \\
\text { consultation }\end{array}$ \\
\hline 2 & Passive participation \\
\hline 1 & Manipulative participation \\
\hline
\end{tabular}

Figure 2 Pretty's participation typology

Fredrik defined seven levels of participation, compares them to Arnstein's. The architect also uses forms and levels of participation in design. The explanation of the seven methods is in Figure 3 [24].

\begin{tabular}{|l|}
\hline Self-decision \\
\hline \hline Co-decision \\
\hline \hline Alternative \\
\hline \hline Dialogue
\end{tabular}

Figure 3 Fredrik's participation typology 
In the book A Framework for analyzing Participation in Development by the Norwegian Agency for Development Cooperation, the approach proposed to analyze participation must consider: 1). Who participates, for instance, the extent to which gender, age, economic or social factors influence the profile of participation whether this is individual or collective; 2). Their motives for participation, which may include the expectation of direct or indirect benefits, or motives that are more altruistic, or based on a commitment to particular values or ideals; 3 ). The extent to which the preconditions for each form of participation to be effective in exerting influence or changing outcomes are in place such as the availability of accurate information, and a decision-making process that is not dominated by other interests to such an extent that local participation cannot exert any influence; 4). The result of participation, which may in some appropriate cases be ranked on a scale of empowerment, but which may also take other forms, including increased coverage of services delivered, better alignment with local needs and priorities, improvements in the quality and accountability for service provision, or broader social learning in addressing complex challenge [18].

The term participatory in design is referring to the activity of designers and people not trained in design working together in the design and development process. In the practice of participatory in design, the people who are being served by designers are no longer seen simply as users, consumers, or customers. Instead, they are seen as the experts in understanding their ways of living and working. They are seen as valuable partners in the design and development process. This mindset contrasts with a user-centered mindset that recognizes researchers and designers as being the experts and relegates the people being served by design to be the research subjects and/or the recipients of the designed object [25].

Users' participation in design and implementation is a major concept that could investigate for several reasons. Users' participation is a good way to improve the quality of residents' life, but it needs the willingness and ability to participate. It is essential to find residents who are willing to offer time and effort to participate. The community should be encouraged and not forced to participate. The local community participates in the design process will not obstruct the implementation. However, they may participate independently and voluntarily in the implementation process and maintain the works in the future. When a user participated, he carried the responsibility with the architect.

Moreover, the user will defend the design in front of others. Participation is the right of users as they support the construction costs. The owners should participate in the design process to achieve a sustainable design which meets the users' needs and desire. Participation is the residents' right since its outcome will affect their life after residing [24].

\section{METHODS}

The methodology employed in this research involves a qualitative study performed by two-step divided into 1). systematic literature review on community perception, preference, and participation in tourism development. 2). case study review. The main aim of this research is to investigate the form of participation in the urban and rural case study and introduce a comprehensive model of community participation. We will also seek to identify the existing participatory condition. Then we will evaluate it to design a proper method; we also analyze different approaches of participatory design in the urban and rural environment [26], [27], [28], [29]. The differences between conventional and participatory action research are that in participatory research, the local community is actively involved in all stages. Both researcher and respondent are active, including in the design of research instruments, interviewing, data analysis, as well as in the reporting, evaluation, and discussion of the results [29].

Qualitative and participatory research methods are best suited to capturing information on issues that are more complex, sensitive, and/or difficult to quantify using more traditional quantitative research methods. Issues around participation, power, and gender relations and inclusion are intangible, and often difficult to define precisely or measure objectively or unambiguously. Qualitative and participatory methods enable researchers to understand better the underlying causal links of interventions and how and why things happen the way they do. Participatory research is often undertaken in a group setting and through visual and activity-based processes. These processes enable the researcher and participants to understand better the complex changes in processes, behavior [18]

Then, we will focus on the literature to find the principals participatory for design and testing the participatory method in a case study. In this regard, both case study 1 and case study 2 will be addressed to find the form or model of the community perception, preference, and participation in tourism development. As the indicators of community perception, preference, and participation in tourism development vary from one context to another, the proposed model is designed in a way to be applicable in different contexts.

\section{RESULT AND DISCUSSION}

\subsection{Case study 1-kampung terapi, Malang city}

Kampung terapi is located in Kecamatan Sukun, $2.3 \mathrm{~km}$ from Malang city. The settlement has a typical modern Indonesian style brick-structured house. It has Javaneseurban middle to lower economy cultural life. The width of house is very varied, ranging from $45 \mathrm{~m} 2,75 \mathrm{~m} 2$ to 125 $\mathrm{m} 2$. 


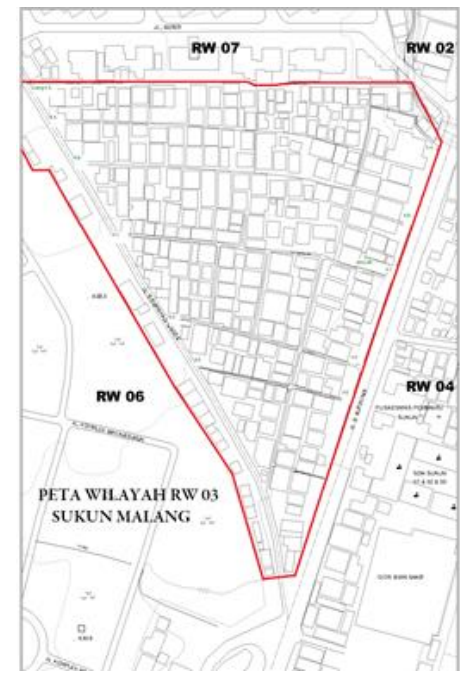

Figure 4 Kampung terapi map

The local community has an occupation as a government employee, private sector employee, house builder, craftsman, and carpenter. The Local people are very active in maintaining environmental safety and hygiene. They made their own garbage bank and actively separate recycle and nonrecycle waste. Non recycled waste is used for handicraft materials. They have a routine activity of making handicrafts made from non-recycle plastic and old newspapers into baskets, ornamental plant pots and various home displays. Some of the young man are painting artists. They usually paint graffiti on the back wall of a house that sits in the aisles
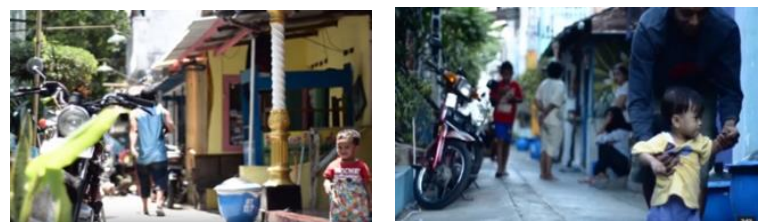

Figure 5 Children-friendly alley condition

Kampung terapi also has bio-composter processing as other educational tourist attraction. Local people are actively collecting waste from plants into a particular garbage bin. In the last few years, kampung terapi have received visitors from various regions in Indonesia to study bio-composter, study crafts, and waste management. Also, there are regular tourist visits to see the atmosphere of urban settlement life.

Kampung terapi has child-friendly zone bordered by a narrow alley of settlements, the place that community usually calls as a children-friendly alley. The width of this children-friendly alley is approximately $1.8 \mathrm{~m}$. In this alley, the small children of the kampung terapi settlement playing traditional games such as crickets, hide and seek, snakes and ladders, and swings. They also has playing tunnel. In 2014, the Department of Architecture of Universitas Brawijaya also assisted in the form of providing children's toy facilities installed in the childfriendly alley.

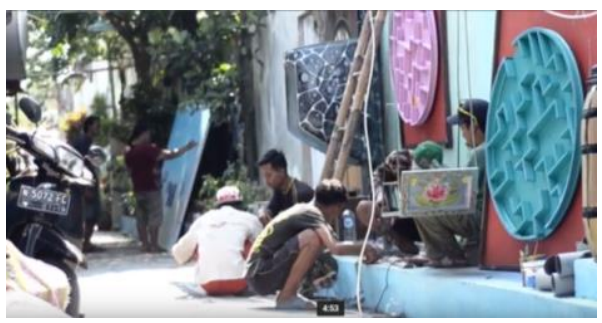

Figure 6 The children toys in the children-friendly alley

UB through Department of Architecture help provide children's play facilities. In this activity in community support program embedded in annual ceremony. The participatory development is applied in this program. The local community are involved in the planning, implementation, monitoring, and evaluation stages.

In this participatory activity, despite there are some differences in views, orientation, and interests of local community several problems can be solved by a good participatory process. They have high sense of belonging of their place and pride. One of the residents involved in the process of this activity argued: "this fieldwork (construction of children's toys) can be done by only the people from this place, there is no need to involve people from outside". From this opinion, it can be concluded both the positive and negative things. The local community tend to not involving outside parties, and they want to be more involved in the process of design implementation.

In 2019, the author through community support program held by Faculty of Engineering, UB help kampung terapi in the making of artistic murals with local community participation, especially those who have skill in art and painting.

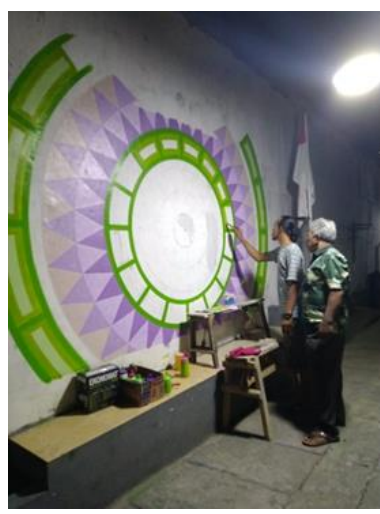

Figure 7 Mural art painting process in the childrenfriendly alley

Through this research, it was found that there was a local institution formed by the local community in kampung terapi development. This institution consists of environmental cadres, community groups in terms of development, and art studio community groups. Related to 
the community service program carried out by the university, the group that plays an active role in the physical development of mural art is a group of environmental cadres.

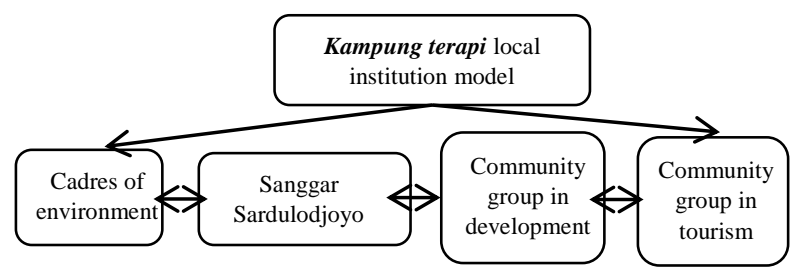

Figure 8 Local institution of Kampung terapi

In children-friendly alley development initiation and gravity support, the level of participation based on Arnstein's ladder of participation is classified as participation by consultation. Several meetings and focus group discussions are conducted to get the design result and development decision. Participatory by consultation in kampung terapi means that the community is involved from the very beginning of the discussion on the proposed development, problem identification, decision making, design making, and evaluation.

\subsection{Case study 2-Sumberwangi Hamlet}

Sumberwangi Hamlet is located in Donowarih village, Karangploso District, Malang region. This hamlet located at the foot of Mount Arjuno, $23.3 \mathrm{~km}$ from the center of Malang. This village has the natural beauty of the mountains, in the form of mountain views and pine forests. It has a population of 37 people. The citizens work as farmers and ranchers. Some citizens have their agricultural land while some work on land owned by others as well as those of Universitas Brawijaya. Most of its local people live in low economy. Preliminary interviews with members of this settlement revealed their needs and aspirations.

Sumberwangi has natural wealth in the form of coffee plants, vegetables, and some fruits. The famous agricultural products are coffee, both robusta and arabica, while the local handicrafts that are being marketed are typical Sumberwangi batik. Sumberwangi and UB Forest have been managed a partnership with university since 2015. Local community worked closely with the UB Forest management and UB lecturer in developing and marketing some agricultural and handicraft products.

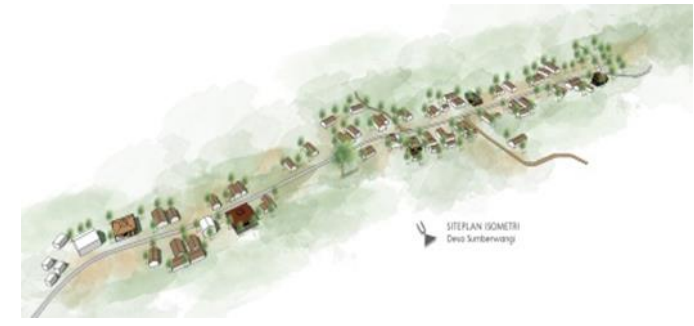

Figure 9 Sumberwangi hamlet siteplan
The visitor could enjoy the unique richness in terms of natural and cultural resources. Natural features include biological diversity, such as distinctive trees. The site encompasses dense coffee trees, shrubs, and few vegetable trees. Visitors could enjoy a variety of wildlife exemplified by migrating birds, local birds, and monkeys. The cultural features that this hamlet has include a traditional settlement of about 57 families descendant of the Javanese tribe. The settlement has its traditional cultural lifestyle in which people speak both traditional Javanese and Indonesian language. Despite the beautiful landscape and culture, it has a possibility of strong wind attack.

In 2018, UB through community support program helped Sumberwangi development. The author and team assisted the local community designed their house to become homestay to accommodate visitor demand for overnight stay. Intensive site analysis studies were conducted utilizing several factors: 1) Environmental context, 2). Topographical features, 5) Natural and cultural attractions, and positive and negative views 6) Climate. Each factor has been investigated in terms of design constraints and responses, thereby establishing a set of planning results to the site. The local community consensus response to climate constraints confirms that the tourist accommodation or homestay should be wind-proof. We proposed an appropriate design for the accommodation based on community consensus.

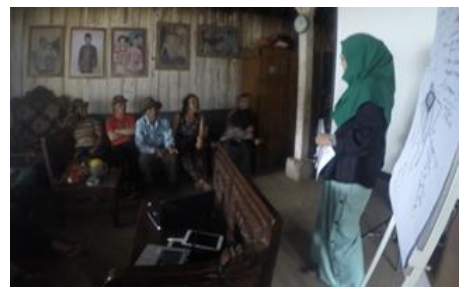

Figure 10 Community consensus-decision making in Sumberwangi

Through this research, we also found the model of Sumberwangi local institution. There are local people together with UB forest management (BUA), academic lecturer, and student. The local community is chaired by village elders as a link between the university and the village. Academic lecturers and students become facilitators in the planning and design process.

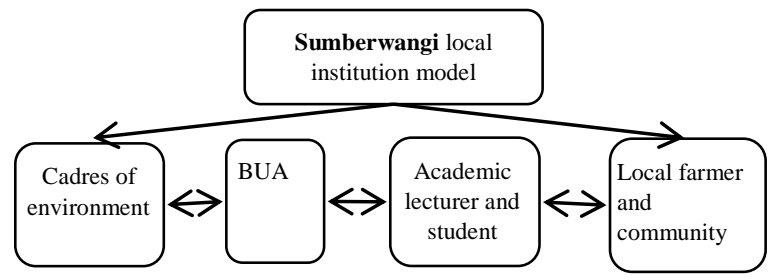

Figure 11 Local institution in Sumberwangi

Through this research, we found that the role of the community in Sumberwangi hamlet ecotourism development was become the main actor of formulating 
the development goal and define the problem. Furthermore, the community support team has role as facilitator to enable the local community of understanding the ecotourism development, reconciling program objectives with community priorities that had been determined.

The level of participation classified as participation by consultation. Several meetings and focus group discussions are conducted to get the design result and development decision [31]. Participatory by consultation in the Sumberwangi case study means that the community is involved from the very beginning of the discussion on the proposed development, problem identification, decision making, design making, and evaluation.

In this activity, several problems can be solved by a good participatory process. Several problems began even in the earlier step of the program. It is mainly because there are some differences in local community and facilitator views, orientation, and interests. One of the residents involved in the process of this activity argued: "If Mr. A's house becomes a pilot project and gets funds for its construction, then what about the other house if the funds from investors are limited?". From this opinion, it can be concluded that there are social gaps, jealousy from some residents regarding the development initiation.

\subsection{Model of participatory for architecture design}

The perception, preferences, and participation of two case studies can reverse depending on each of these factors: 1). Framing effect; 2). Stimulus contexts and environments; 3). Response Mode effects, 3) People characteristic.

It can be synthesized that perception can affect preferences, perceptions can affect participation, and vice versa, preferences can be possible to influence perceptions, and participation can affect perceptions and preferences [17], [19], [20], [21], [22].

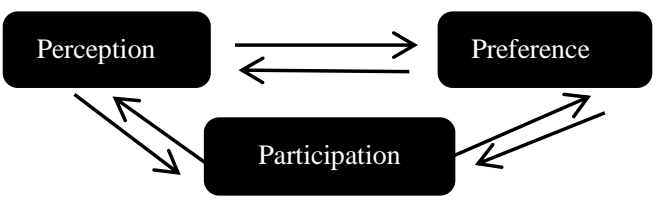

Figure 12 People perception, preference, and participation scheme

Figure 13 illustrates the participatory process that starts from the initial meeting (focus group discussion), design making, discussion of design results, to development, where the community becomes an actor and is actively involved in the whole process.

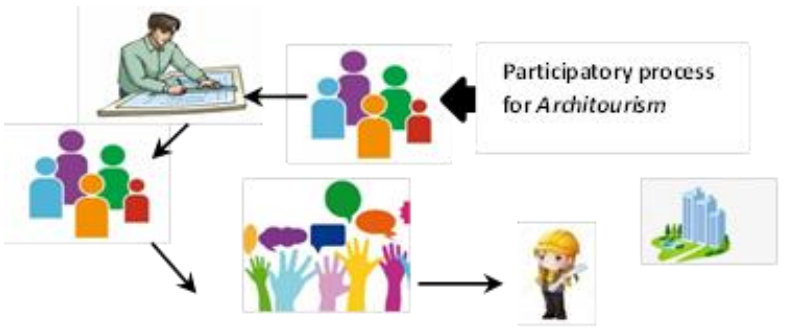

Figure 13 Participatory process in architourism

Adopted from Metatla in designing with people living with visual impairment: audio-tactile mock-ups, audio diaries and participatory prototyping with their, approach to conducting accessible, participatory design [30], also Drake in his proposed community-based development scheme and Giriwati et al. in community-based ecotourism scheme [4], this research propose a new model of participatory for architecture design. The participatory process began from the focus group discussion in the first stage then continued with workshops on design in the later stages, which closed with an evaluation. If there are things that need to be revised, then after the evaluation phase, there may be another workshop stage.

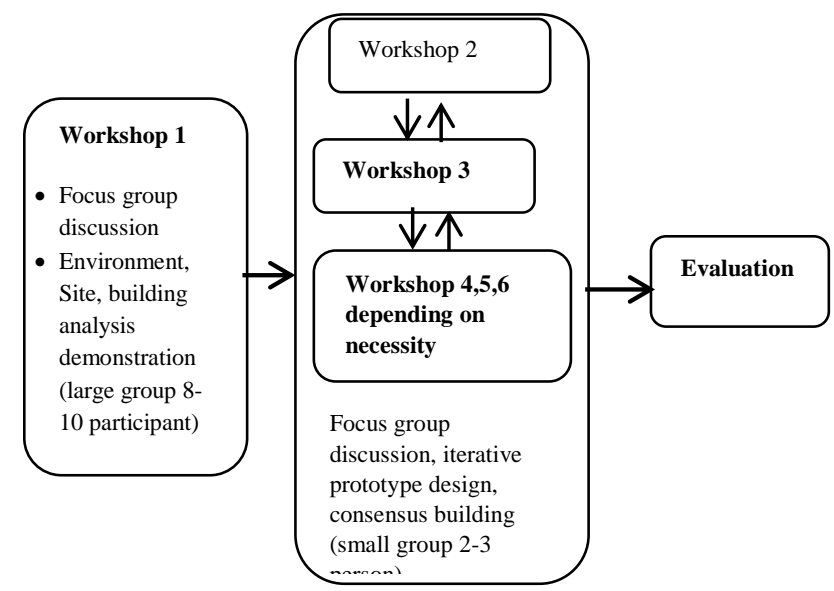

Figure 14 Proposed activity model for participatory in architourism

The participation needs many years of process as other studies done for getting the government approval and the construction works implementation. It is time and moneyconsuming, but it ensured user satisfaction [24]. In order to ensure the sustainability of participatory development, a good institution with good cooperation among the stakeholders is crucial. This institution also has to motivate young people in the village to actively participate in development so that this participatory development can take place in the long term.

Through this research, we also produced a proposed model for institutional schemes that could be applied in both case studies, involving government, local communities, NGOs, the private sector, and academics or universities. 


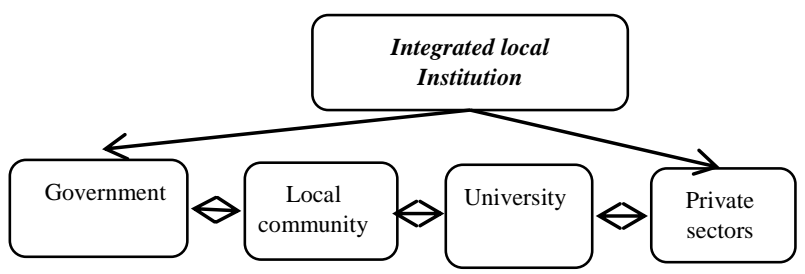

Figure 15 Proposed model for local institution scheme in architourism development.

\section{CONCLUSION}

Throughout this research, it is essential to take into consideration the perception, preference, and participation in the design process. It was found that good perceptions and preferences will build a good participatory process. Based on two case studies, the participation level in consultation stage is important and offers great hope for successful development. The good perception and preference is good beginning. If at the beginning of the activity, residents have a good perception, furthermore in the process of extracting ideas, the formulation of design concepts by exploring their preferences, good ideas will be found. So that then the participatory will go well with the involvement of all relevant parties.

The participatory approach for planning and designing clearly emphasizes that the process has influenced the quality and acceptance of the project. Engaging the community key actors together with experts in a structured process provided the necessary stage to move forward to implementation stage. Using participatory techniques for decision-making should be seen as a strategy for involving all key players, where creativity and innovation can be achieved by having all concerned parties involved in the process while identifying the best collaboration model and strategy.

A participatory design process required an understanding, development, and mutual partnership. This mutual scheme included all parties gathering to find the different options of design that will and consider the benefit and problem in the future. All actors gained increased knowledge and understanding. Participatory can be a design method in the field of architecture and tourism that is expected to produce good quality of results, minimize errors, minimize social issues and different interests, acceptable and adaptable to all parties, sustainable, and ensure user satisfaction.

\section{ACKNOWLEDGMENT}

The authors greatly appreciate the Research and Community Support Organization of Universitas Brawijaya, Department of Architecture and BUA, which allowed this study to be conducted as part of Universitas Brawijaya's event, research, and development project.

\section{REFERENCES}

[1] D. M. Lasansky, B. McLAren, Architecture and tourism: Perception Performance, and Place. USA: Berg. 2004.

[2] M. Scerri, D. Edwards, C. Foley, "Design, architecture, and the value to tourism", Tourism Economic 1-16. Sage publisher. 2018.

[3] K. Power, R. W. Brock. Understanding Architecture Decision in Context: An Industry case study of architects decision-making context

[4] P. D. Plowright, "Revealing Architectural Design: Method, Framework \& Tools," Lawrence Technological University. London and New York: Routledge Taylor \& Francis. 2014

[5] D. Pop, "Space Perception and Its Implication in Architectural Design," Acta Technica Napocensis: Civil Engineering \& Architecture Vol. 56, No. 2. 2013, 211 221.

[6] M. Gjerde. Evaluating the visual qualities of urban streetscapes. Thesis. England: Oxford Brookes University. 2009

[7] S. J. T. Jansen, C, C, H, Coolen, and R. Goetgeluk, R. The Measurement and Analysis of Housing Preference and Choice. Netherland: Springer. 2011

[8] C. Warren, A. P, Mc Graw, L. V. Boven, "Values and Preference: defining preference construction". Advance review. 2007. John Willey \& Sons, Ltd.

[9] J. Q. Tritter, \& A. Mc Callumb, "The Snakes and Ladders of User Involvement: Moving beyond Arnstein," Health policy, Elsevier, 76 .2006. 156-168.

[10] N. Carpentier, "The concept of participation. If they have access and interact, do they really participate?" CM, Communication Managemnet Quarterly, 2012. 21:13-36.

[11] D. Rukmana, "Upgrading Housing Settlement for the urban poor in Indonesia: An Analysis of the Kampung Deret", Program. Singapore: Springer Nature Singapore. 2018.

[12] I. A. W Hutama. Exploring the sense of place of an urban kampung.: Through the daily activities, configuration of space and dweller's perception: case study of kampung code, Yogyakarta. Thesis. Universiteit van Amsterdam. 2016.

[13] S. Funo, N. Yamamoto, J. Silas, "Typology of Kampung Houses and Their Transformation Process: A Study on Urban Tissues of an Indonesian City," Journal 
of Asian Architecture and Building Engineering Vol 1, 2002. Issue 2. Taylor \& Francis.

[14] S. Temple. Perceptual Experience and Its role in architectural design decision making. Experiential Simulation: The Sensory Perception of the built Environment. Track 2 Journal, 2013, 289-296.

[15] B. A. Mellers, A. Schwartz, A. D. J, Cooke, "Judgment and decision making. Annual Report of Psychology," 1998. 49:447-77.

[16] M. R. Delgado, E. A. Phelps, T. W. Robbins, "Decision making, affect, and learning attention and performance,” XXIII, New York: Oxford University Press Inc, 2011.

[17] B. K. L. Mak, L. T. O. Cheung, D. L. H. Hui, "Community Participation in Decision-Making Process for Sustainable Tourism Development in Rural Areas of Hongkong, China”. 2017. Sustainability. 2017, pp 1-13

[18] A Framework for analyzing Participation in Development. Norwegian Agency for Development Cooperation. Norwegia ISBN 978-82-7548-773-3.

[19] A. D. Rowe, L. N. Wood, "Student perceptions and Preferences for feedback," Asian Social Science, January 2008.

[20] M. Birenbaum. Assessment for learning. Higher education 33: 71-84. Kluwer Academic Publisher. Netherland. 1997.

[21] S. Mendolia, I. Walker, "The effect of personality traits on Subject Choice and Performance in High School: Evidence from an English Cohort". IZA Discussion Paper No. 8269. IZA: Germany. 2014.

[22] H. Bolhari, T. Dasmah. "Personality Preference: Are Learners and Teachers at Loggerheads?" Procedia Social and Behavioral Science 70, 2013, pp 1636-1640.

[23] N. K Upamannyu, G. Mathur, S. S. Bhakar, "The connection between Self Concept (Actual Self Congruence \& Ideal Self Congruence) on Brand Preference," International Journal of Management Excellence Volume 3 No. 1. Techmind Reseach: India, April 2014.

[24] S. M. S., Ammar, K. Ali, N. A. Yusof, "The effect of Participation in Design and Implementation Works on User Satisfaction in Multi-Stirey Housing Projects in Gaza, Palestine. World Applied Sciences Journal 22 (8): 2013, pp. 1050-1058.

[25] E. B. N. Sanders, P. J. Stappers, "Co-creation and the new landscapes of design," CoDesign Vol.4, No. 1, Taylor \& Francis. March 2008
[26] S. M. Mahabadi, H. Zahibi, H. Majedi, "Participatory Design: A New Approach to regenerate the Public Space. International Journal of Architecture and Urban Development," Vol 4, No. 4, 2014 pp.15-22.

[27] I, N, S Arida, P, P, K Wiguna, I, W, Narka, N, K, O Febrianti, "Development Planning of Tourist Village Using Participatory Mapping (Case Study: Mambal Village, Badung Regency, Indonesia,”. IOP Conf. Series: Earth and Environmental Science 98, 2017 pp. $1-10$.

[28] D. Lutfiyah, Herlily, "Participatory in kampung's co-housing development: Learning from Kampung Muka, North Jakarta," CSID Journal of Infrastructure Development (2) 1: 74-83. 2019.

[29] B. V. Heck. Participatory Development: Guidelines on Beneficiary Participation in Agricultural and Rural Development. $2^{\text {nd }}$ Edition. Italy: Rural Institution and Participation Service, Rural Development Division, Food and Agriculture Organization of the United Nations. 2003.

[30] O. Metatla, B. Kinss, N. Stockman, T. Martin, "Designing with and for people living with visual impairments: audio-tactile mock-ups, audio diaries and participatory prototyping, "CoDesign 1-12. Taylor \&Francis, April 2007.

[31] N. S. S. Giriwati et al. "Local Community Participation in Ecotourism Development: The case of Sumberwangi Hamlet Destination, East Java, Indonesia," People: International Journal of Social Sciences Volume 5 Isuue 1, 2019, pp. 81-98.

[32] N. Ricci. The Psychological Impact of Architectural Design. Thesis. Claremont McKenna College. 2018.

[33] K. Ryu, S.S. Jang, “The Effect of Environmental Perceptions on Behavioral Intentions Through Emotions: The Case of Upscale Restaurants," Journal of Hospitality \& Tourism Research, Vol. 31, No. 1, February, 56-72. International Council on Hotel, Restaurant and Institutional Education. 2007.

[34] A. Sorensen, H. Koizumi, Miyamoto, “A. machizukuri, civil society, and community space in japan. Living cities in japan: citizens' movements, machizukuri and local environments". USA: Routledge. 2009. 